DOI https://doi.org/10.36059/978-966-397-113-1/157-176

\title{
INTERNATIONAL STANDARDS IN THE FIELD OF HUMAN RIGHTS PROTECTION AS A COMPONENT OF LEGAL POLICY OF THE STATE AS FOR TEMPORARILY OCCUPIED TERRITORIES
}

\section{Iliashko O. O.}

\section{INTRODUCTION}

The main task of the state legal policy under the conditions of a hybrid war is to create an effective normative-legal basis for proper counteraction to hybrid threats as well as for taking preventive measures, eliminating separatist spirits and destructive consequences for the state, society, and people etc. Practical embodiment of theoretical achievements on this issue can determine the further development of Ukrainian legal system.

Our state strives for embodiment of constitutional norms concerning human rights and freedoms provision, but there are still some problem issues necessary to be resolved. The issue of ensuring rights for persons, living at temporarily occupied territories, requires further legal regulation. Moreover, the part of constitutional-legal norms, guaranteeing human rights, has no mechanisms for their exercise at the temporarily occupied territories that gives a reason for discussion among scientists and practitioners.

For that reason the necessity to develop effective state legal practice at the temporarily occupied territories under the conditions of hybrid war arises and it is a part of the state policy that is justified and consistent activity of state authorities, self-government bodies aimed at effective mechanism of legal regulation of public relations at the temporarily occupied territories under the conditions of hybrid war and is reflected in a set of ideas, measures, tasks, programs, guidelines exercising in the filed of law and by virtue of law and it is based on fundamental law principles.

\section{Problems of Legal Regimes of Annexed and Occupied Territories}

Since the beginning of occupation of The Crimean Peninsula and armed conflict in Donbas, Ukraine has experienced the hardest 
humanitarian crisis in its history. In the Order of the Verkhovna Rada of Ukraine On recommendations of Parliament hearings on the subject "The state of observing rights of internally displaced people and citizens of Ukraine living at the temporarily occupied territory of Ukraine and at temporarily uncontrolled territory in the area of anti-terrorist operation it is said about the following: "... In Ukraine the events took place that influenced human rights provision of the majority of people in the state fundamentally and dramatically. As a result of unhidden aggression of Russian Federation in March 2014, the Autonomous Republic of Crimea was annexed and an armed conflict was started in Donetsk and Luhansk regions",

Today, the state is working towards stabilization of situation, guarantee of constitutional rights and freedoms of citizens at the annexed and occupied territories. The legal basis is being developed, the Ministry on Issues of Temporarily Occupied Territories and Internally Displaced People has been established as a coordinator of central executive body as well.

The logic of such steps is to observe the provisions of Article 3 of Basic Law of Ukraine: A person, his/her life and health, honesty and dignity, inviolability and safety are recognized in Ukraine as the highest social value. Human rights and freedoms as well as their guarantees determine the content and orientation of the state activity. The state is responsible to a person for its activity. Establishment and provision of human rights and freedoms is a main duty of the state" ${ }^{\text {. However, today }}$ it is difficult to execute these provisions in the present military-political situation because not all steps taken are effective enough. As T. Popova emphasizes, "instead of implementation of the holistic information policy, many measures were taken, in fact, manually in the area of anti-terrorist operation in Ukraine, often balancing on the threshold of permitted"3. Thus, legal science has an urgent problem such as studying the legal regime of the annexed and occupied territories.

\footnotetext{
1 Про Рекомендації парламентських слухань на тему: «Стан дотримання прав внутрішньо переміщених осіб та громадян України, які проживають на тимчасово окупованій території України та на тимчасово неконтрольованій території в зоні проведення антитерористичної операції»: Постанова Верховної Ради України від 31.03.2016 р. № 1074-VIII. URL: http://zakon0.rada.gov.ua/laws/show/1074-19.

2 Конституція України: Закон України від 28.06.1996 р. № 254к/96-ВР. Дата оновлення: 21.02.2019 p. URL: http://zakon2.rada.gov.ua/laws/show/254к/96-вр.

3 Попова Т. До питання відновлення суверенітету України над тимчасово окупованими територіями. URL: https://www.google.com.ua/url?sa=t\&rct=j\&q=\&esrc=s\&source=web\&cd=33\&cad $=$ rja\&uact=8\&ved=0ahUKEwj_tO6gi_XXAhWsZpoKHbW4Cxw4HhAWCDYwAg\&url=https\%3A\%2F\%2F www.radiosvoboda.org\%2Fa\%2F28842999.html\&usg=AOvVaw0TAk1KLnYOb3JSfhpSpwwW.
} 
Since 2014 there have been discussions among professionals on sovereignty of Ukrainian state, normative regulation of counteraction to Russian aggression. However, both scientists and practicing lawyers as well as politicians often substitute such fundamental concepts as "aggression", "annexation", "occupation", "hybrid war", "hybrid occupation" etc. To eliminate contradictions one should study a legal regime of annexed and occupied territories, determine the concepts of annexed and occupied territories, peculiarities of their legal regime.

The concept of "aggression" in politics After events in 2014 in the Autonomous Republic of Crimea the word "annexation" was introduced in various public discourses actively, and the word "occupation" - from the beginning of armed actions in Eastern Ukraine. Both these concepts are attributed to the third one, namely, aggression because annexation and occupation are various types of aggression. In this context, O. Zadorozhny, the author of the monograph "Annexation of Crimea International Crime" (2015), emphasizes that aggression is "the gravest international crime violating imperative norms of international law and putting at threat international law order and key values for all state and world society in general. For that reason, international-legal liability of an aggressor state has considerable peculiarities: it appears to both affected state and international society in general" 4 .

The deep reflection of aggression issue at the international level started after the World War II because that war revealed global problems in the fields of peace stability and human rights guarantee. The world community, almost for the first time in history, re-evaluated the meaning of democratic principles of public order, human rights and freedoms. The regime of German National-Social Labor Party, lead by A. Hitler is associated with various manifestations of aggression: violence on a massive scale, genocide, racism, and dictatorship.

For that reason, during post-war period the theory of natural law was revived, the idea of non-alienation of human natural rights regardless skin color, origin, property status was spread. The idea of a new international law order based on values of fundamental human rights and freedoms was established. Therefore, institutional mechanisms of human rights protection were renewed: they transferred from mere internal state competence ant obtained international meaning. At the same time, the

\footnotetext{
${ }^{4}$ Задорожній О. В. Анексія Криму - міжнародний злочин: монографія. Київ: К.І.С., 2015. 576 с.
} 
awareness that it was necessary to provide the exercise of human rights and freedoms both at global and regional level appeared.

In Europe, which suffered from that war the most, integration and coordination processes started due to which a historical document Convention for the Protection of Human Rights and Fundamental Freedoms was signed at the session of Committee of Ministers of the Council of Europe in Rome. In a modern education literature it is often said about meaning of this event in such a way: "Adoption of the European Convention for the Protection of Human Rights and Fundamental Freedoms became a revolutionary event in international law of that time because the latter not only determined a certain list of human rights and freedoms as it was in the Universal Declaration of Human Rights, but also created special provisions having obtained powers to carry out judicial and quasi-judicial supervision on its provision observance and to consider claims from private people v. states" 5 .

On January $21^{\text {st }}, 1959$ The European Court of Human Rights as a unique international justice body (ECHR) was established, jurisdiction of which covered member-states of the Council of Europe. According to Article 19 of the European Convention on Human Rights, "to ensure the observance of the engagements undertaken by the High Contracting Parties in the Convention and Protocols there shall be set up a European Court of Human Rights... It functions on a regularly basis" $"$.

Thus, the issue of aggression in internal and foreign policy in the middle of $20^{\text {th }}$ century began to resolve on the very basis of provision of human rights and freedoms.

As O. Zadorozhny wrote, giving international legal qualification to the actions of Russia against Ukraine, first of all, it is worth noting about the gravest crime against peace and safety - trigger and conduct of an aggressive war. "...aggression is understood, on the one hand, as an action, for which states are responsible, on the other hand, as a crime of physical persons, providing individual liability under international criminal law"7.

\footnotetext{
5 Тлумачення та застосування Конвенції про захист прав людини й основоположних свобод Свропейським судом 3 прав людини та судами України : навч. посіб. / [М. В. Мазур, С. Р. Тагієв, А. С. Беніцький та ін.]; за ред. В. М. Карпунова. - Луганськ: РВВ ЛДУВС, 2006. 600 с.

6 Свропейська конвенція 3 прав людини. URL: https://www.echr.coe.int/Documents/ Convention_UKR.pdf.

7 Задорожній О. В. Анексія Криму - міжнародний злочин: монографія. Київ: К.І.С., 2015. 576 с.
} 
In dictionaries the concept "annexation" means (Latin annexioattachment) "violent attachment (seizure) of a part or all territory of one state or people by another state, forced keeping of people within the borders of another state"8. Under annexation, the state borders are imposed violently, contrary to the will of its population, which is incompatible with the basic principles of modern international law and the UN Charter. In accordance with the UN Charter (Article 1;2), members of this organization must adhere to the principle of equality and selfdetermination of people and refrain from threats of force or its application against the territorial integrity and political independence of any state. Annexation is a gross violation of contemporary international law.

Throughout the history of mankind it was through the annexation that the territories were obtained. Annexations were associated with conquests and were considered the winner's right. This is how the wars were traditionally ended during the slave-owing system and feudal epochs as well as during the time of capitalism. In a number of cases, annexation is considered to be some colonial seizure, and a kind of annexation - the creation of states with puppet regimes.

As history proves, annexation for Ukraine is a new concept comparing to other states (Manchu state, 1932 and others).

The concept of "occupation". In academic interpretation it is determined: "Occupation is a temporarily seizure of a part or all territory of one state by armed forces of another one".

In the "Dictionary of Foreign Words" the etymology of the word is traced from Latin occupatio - to conquer, seize and the following semes:

" 1 . It is a temporarily occupation by armed forces of a part or the whole territory of one state by another state, mainly as a result of offensive hostilities; occupation, enslavement.

2. In the Ancient Rome: seizure of things having no owner, including land plots" ${ }^{\prime 10}$.

According to international law norms, occupation regime, not taking into account its immanent unlawful nature, is governed by several conventions: 4th Hague Convention (1907); Geneva Convention for the

\footnotetext{
8 Короткий термінологічний словник. URL: https://pidruchniki.com/11800408/istoriya/ politichna_istoriya_ukrayini_slovnik

9 Словник української мови. Академічний тлумачний словник (1970-1980). URL: http://sum.in.ua/s/okupacija.

${ }^{10}$ Словник іншомовних слів. URL: http://slovopedia.org.ua/36/53406/244881.html.
} 
Protection of Civilian Persons in Time of War (1949); The Hague Convention for the Protection of Cultural Property in the Event of Armed Conflict (1954).

The annexation and military occupation are not legal grounds for changing the state territory. No territorial changes, made by annexation or military occupation, can be legally enshrined. Therefore, it is prohibited to include occupied territories in the occupier state in accordance with international law norms.

Military occupation, in contrast to the annexation, does not create legal grounds for changing the state territory - affiliation (title) of the territory, moreover, regardless of the occupation duration.

Since the occupying power at the occupied territory establishes its own law order, international law imposes an obligation on the occupier state concerning the state which it occupies. The occupier state, as S. Poltavets emphasizes, "has the right to levy taxes on the occupied territory, to demand that the population obey its established norms and laws. At the same time, the occupying power is deprived of the right to force citizens residing at the territories seized by it to assist it (the occupying power) in carrying out military operations against their homeland.

Basic human and civil rights, including the right to property, private and personal rights, should be ensured at the occupied territory. International law norms provide for the right of citizens to remain loyal to their state. At the same time, the occupier has the right to increase criminal liability and introduce certain norms into criminal legislation at captured territories, providing for the reinforcement of punishment for violating the safety of its military formations or property. Non-compliance with international law norms by the occupier state leads to political, moral and material sanctions for crimes that are particularly dangerous, including the criminal liability of specific officials or ordinary citizens. Such liability may arise due to violation of laws and customs of war and for crimes against peace, humanity, human safety and international law order by the occupier state or its representatives"

The concept of "hybrid war" In Ukrainian jurisprudence, a "hybrid war" is rather new concept, and not enough studied. It has been

11 Полтавець С. Окупація земель суверенної держави: уроки політичної історії. URL: http://nbuviap.gov.ua/index.php?option=com_content\&view=article\&id=972:okupatsiya-zemel-suverennojiderzhavi\&catid $=8 \&$ Itemid $=350$. 
introduced into an active discourse in recent years, in connection with Russian aggression. Ukraine faced the challenge of defending state sovereignty and borders under the conditions of hybrid war having other means than, for example, the World War II. Therefore, one should rethink the war phenomenon, its course and consequences, react quickly, and develop radically new approaches. It should be noted that in the modern war, the use of information and communication technologies, highly skilled human resources, the art of international politics, the re-equipment of economy etc. has been of great significance.

A hybrid war is a complex and inert process, it is not always manageable, it can not be stopped "by the order from the top". Unlike the traditional wars of the past, it does not end with the signing of a truce agreement.

The field of application of hybrid war tools does not have wellestablished "battle lines" - it is too broad: population of the conflict zone; rear population; international community.

The hybrid war is still called asymmetric, taking into account that rivals may not be equal in it, but this does not mean that someone who has more resources will win. O. Kurban notes: “... During a hybrid war, the resources and nature of actions of rivals may differ from each other. The main goal is compensate a lack of resources and capabilities through a certain concentration of one of the parties or to gain significant advantage in a particular direction within the conflict" $" 12$. In a view of this, when developing and implementing the state legal policy under the conditions of a hybrid war, it is necessary to look for new approaches to its definition, clarifying the nature, content and features of this phenomenon.

In our opinion, a hybrid war is an organized struggle between states that has a specific creative nature: it is conducted through non-standard strategies and tactics, with the involvement of a set of political, military, economic, information, ideological tools and means.

Practice shows that separatist ideas, views and actions are actively spreading under the hybrid war conditions. Proponents of separatism, pursuing their goals, can use both non-violent methods and armed struggle. Typical forms of non-violent actions are organization of referendums, propaganda campaigns, mass meetings, expanding of party

\footnotetext{
12 Курбан О. В. Теорія інформаційної війни: базові основи, методологія та понятійний апарат. Scientific Journal «ScienceRise». 2015. № 11/1 (16). C. 95-100.
} 
activities, public movements. The armed struggle can take the form of sabotage, terrorist acts, rebel and partisan actions, etc.

Opposition to separatist movements is connected with renovation of control over temporarily occupied territories, the regime of the state border by the state authorities, which is especially important under the conditions of armed confrontation. This allows blocking the channels of financial and material resources, staffing of militants, and influencing their command and control systems. The political and legal settlement of separatist conflicts should be based on the need to protect national interests, territorial integrity and inviolability of state borders, rights and legitimate interests of local population.

The Constitution of Ukraine clearly defines the concepts of "war" (Articles 85, 106) and "martial law" (Articles 41, 43, 64, 83, 85, 92, 106, and 157). The lawmaker describes the order of announcement of the state of war, martial law, the order of mobilization, forced alienation of property, public works in such conditions.

The concept of "hybrid occupation". Hybrid occupation, or effective control, is a new category in legal discourse, which means the newest form of control of foreign territories (temporarily occupied and annexed) with the minimum use of force methods.

In a modern political reality, even an aggressor-state, preferring to pursue an aggressive policy, must take care of its international image and seem to be civilized. Therefore, the aggressor-state resorted to use a more subtle form of occupation, namely, hybrid one. It is based on effective control, which, according to the official website of the Ministry for Temporary Occupied Territories and Internally Displaced Persons, provides:

"Conducting continuous military actions by non-state armed groups against government forces of one state, with the support of another state, without which the groups mentioned, could not carry out their activities. In particular, such support can be political, military, economic, financial, and social. Non-state armed groups can create "power bodies" with the support of another state cooperating with these "bodies" and may delegate their representatives to them" 13 .

\footnotetext{
${ }^{13}$ Окупація та ефективний контроль: національне сприйняття та міжнародно-правові реалії. URL: https://mtot.gov.ua/okupatsiya-ta-efektyvnyj-kontrol-natsionalne-spryjnyattya-ta-mizhnarodno-pravovi-realiyi.
} 
According to V. Gorbulin, a "hybrid occupier" aims to achieve political goals with minimal armed influence on the enemy. These approaches relate to the situation prevailing in certain districts of Donetsk and Luhansk regions, which are not under the control of Ukrainian authorities ${ }^{14}$.

Russian occupation of the Crimean Peninsula: legal regime at the temporarily occupied territory of Ukraine. Occupation is not a new concept in the history of Ukraine. For example, in 1941-1944 was the period of Ukrainian lands under German rule after the retreat of Soviet troops. The occupiers carried out colonization policies, exploited the population, planned to incorporate the Ukrainian territory into the German Reich. This is classical military occupation, that is, a temporary seizure of the territory of a certain state by armed forces of another state, which often occurs during international armed conflicts.

In the $21^{\text {st }}$ century Ukraine suffered from occupation again, namely, from the Russian Federation. We propose the following definitions of this phenomenon:

The occupation of the Autonomous Republic of Crimea and Sevastopol by Russia is, first of all, the armed aggression has committed by Russia since February 20, 2014, aimed at alienating the Crimea and Sevastopol autonomy from Ukraine and their annexation to their own territories as subjects of the Russian Federation; and secondly, keeping Ukrainian territories in the Russian Federation composition in a violent way and with systemic violations of international law.

The temporarily occupied territories include:

1) The land of the Autonomous Republic of Crimea and Sevastopol, internal waters of Ukraine of these territories;

2) Internal sea waters and the territorial sea of Ukraine around the Crimean Peninsula, the territory of the exclusive (maritime) economic zone of Ukraine along the coast of the Crimean Peninsula and the coastal continental shelf of Ukraine, which is subject to jurisdiction of Ukrainian state authorities in accordance with norms of international law, the Constitution and laws Ukraine;

14 Горбулін В. Гібридна війна: все тільки починається ... Дзеркало тижня. 25.03.2016 р. № 11. URL: http://gazeta.dt.ua/internal/gibridna-viyna-vse-tilki- pochinayetsya-html. 

$\operatorname{part}^{15}$.

3) Airspace over the territories specified in clause 1 and 2 of this

Ukraine as well as the UN General Assembly, the PACE, and the OSCE PA will not recognize the annexation of Crimea. In contrast, the Russian Federation speaks about "the return of the Crimea to Russia". In accordance with the Law of Ukraine "On ensuring the rights and freedoms of citizens and legal regime in the temporarily occupied territory of Ukraine", the territory of the Crimean peninsula is a temporarily occupied territory.

On March 27, 2014, the General Assembly of the United Nations adopted a Resolution on the territorial integrity of Ukraine, which lists the international legal documents that the Russian Federation violated.

The UN General Assembly resolution disapproved the holding of a referendum at the Crimea and Sevastopol territory and made a conclusion that the referendum was unlawful. The resolution calls on international community not to recognize any changes in the Autonomous Republic of Crimea status.

Legal regime of occupied territory. The occupation of a certain territory by the aggressor-state does not terminate the legislation effect all the legislative acts are in force at the occupied territory. Therefore, Ukrainian lawmakers and lawyers assign a high priority to such complex theoretical and practical problem as the regime at temporarily occupied territory of Ukraine, introduced in connection with Russian occupation.

The legal regime of the occupied territory in Ukraine is governed by the following normative legal acts, such as: the Constitution of Ukraine; the Criminal Procedural Code of Ukraine, the Code of Administrative Offences of Ukraine (Articles 202, 204); Laws of Ukraine "On ensuring the rights and freedoms of citizens and legal regime in the temporarily occupied territory of Ukraine"; "On border control"; the Criminal Code of Ukraine (Articles 332, 438), as well as the Order of the Cabinet of Ministers of Ukraine "On the temporary closure of checkpoints across the state border and control points", etc.

An important regulator of a legal regime at the temporarily occupied territory is the Constitution of Ukraine and implementation of constitutional and legal policy - a justified, systematic activity of the state

\footnotetext{
15 Правовий режим окупованої території. URL: http://www.i-law.kiev.ua/правовий-режимокупованої-території/
} 
and territorial bodies and public associations with the aim of optimizing the constitutional development of these territories. The Constitution of Ukraine is the basic legal act, establishing basic principles of public life organization and strategic goals of state development. Constitutional legislation is implemented through constitutional and legal policies - such policy forms a legal system, it is the basis of it. In a hybrid war, the state must, first of all, provide the stability of legislation, including the Constitution, in order to prevent legal nihilism, people's disbelief in the state's ability to protect their rights and freedoms. Secondly, in view of relevant development of public relations, the state is obliged to adaptively respond and provide the development of legal policy.

After the Crimea annexation, the Law of Ukraine "On ensuring rights and freedoms and legal regime in the temporarily occupied territory of Ukraine" was adopted (came into force on April 15, 2014), aimed at legislative regulation of the situation. Article 1 of this document states: “... The temporarily occupied territory of Ukraine is an integral part of the territory of Ukraine, which is subject to the Constitution and laws of Ukraine. It provided with the first conceptual answers to the challenges, numerous specific issues that the Crimeans and authorities have faced: Ukrainian citizenship preservation, wealth, bank savings, document circulation, blocked pensions, access to education, etc. The main thesis of the Law is that "the compulsory automatic acquisition of citizenship of the Russian Federation by Ukrainian citizens, residing at the temporarily occupied territory, is not recognized by Ukraine and is not a ground for the loss of citizenship of Ukraine". So, despite the fact that the Crimeans acquired the citizenship of the aggressor-state automatically and by force at the territory of the annexed peninsula, Ukraine does not recognize this, and the Crimeans are Ukrainian citizens for Ukraine.

As a result of territory definition of the Autonomous Republic of Crimea as occupied, all newly created state bodies and local selfgovernment bodies there, as well as all acts issued by them, are not recognized in Ukraine. For that reason, the Crimean citizen who received a document there during occupation (passport, driving license, birth certificate or marriage, etc.) can not use it at the territory of Ukraine.

The Law contains provisions on ensuring the exercise of social rights of citizens. There are provisions on social protection, however, this part of the law is rather declarative, than suitable for practical application. 
Considering the Law of Ukraine "On ensuring the rights and freedoms of citizens in the temporarily occupied territory of Ukraine", S. Humphries, professor of London School of Economics noted: "The territory is considered occupied when it is under the direct control of enemy army. Such formulation is given in the Hague Convention of 1907". At the same time, a scholar believes that the "law on occupation" does not have any status in international law, except the fact that the state "thinks so", which has adopted such a law ... Both Georgian and Ukrainian law can not "create" occupation, or "announce" about it. They (these laws) can only draw the attention of international community to what is happening" $"$.

\section{International Cooperation in the Field of Protection of Human Rights and Freedoms at the Temporarily Occupied Territory}

The fact of hybrid occupation over the temporarily occupied Ukrainian territories by the RF is recognized by international community. In case of granting the relevant status to these territories by national law, this fact can not be disputed under international law.

Ukraine, having suffered from a hybrid war and protecting European values under such difficult conditions, is interested in expanding international cooperation.

Costas Paraskeva writes as follows on importance of such cooperation: "In order to prevent the emergence of preconditions for forced displacement of people, protection and observance of rights and freedoms of IDPs, in order to create and maintain conditions that allow such persons voluntarily, under safe conditions and with dignity to return to the abandoned place of residence, as well as conditions for the integration of IDPs into a new place of residence in Ukraine, Ukrainian cooperation with other states and international organizations is of great importance.

The Council of Europe makes a great contribution to IDPs' protection through setting of standards, monitoring and cooperation applicable to 47 member states in Europe."17.

16 Полтавець С. Окупація земель суверенної держави: уроки політичної історії. URL: http://nbuviap.gov.ua/index.php?option=com_content\&view=article\&id=972:okupatsiya-zemel-suverennojiderzhavi\&catid $=8 \&$ Itemid $=350$.

${ }^{17}$ Paraskeva Costas. Protecting internally displaced persons under the European convention on human rights and other Council of Europe standards: a handb. Харків: Рravo, 2017. 130 p. 
The Parliamentary Assembly adopted a number of resolutions on the Ukrainian issue: 2133 (2016) "Legal remedies for human rights violations on the Ukrainian territories outside the control of the Ukrainian authorities"; 2132 (2016) "Political consequences of the Russian aggression in Ukraine"; 2198 (2018), as well as Recommendation 2119 (2018) "Humanitarian consequences of the war in Ukraine related to military actions in Ukraine".

International cooperation during hybrid war, being implemented on the basis of European human rights standards, enshrined, in particular, in the following documents of the Council of Europe, the EU: the European Convention for the Protection of Human Rights and Fundamental Freedoms; European Social Charter; European Union Charter on Fundamental Rights.

These documents clearly articulated indicators and criteria for the content and scope of relevant rights, which is the guideline or duty of the state.

Today, the EU institutions in cooperation with Ukraine are actively appealing to the European Convention for the Protection of Human Rights and Fundamental Freedoms (ECHR), in which they see an effective legal instrument. The ECHR reflects the most important human rights and freedoms: the obligation to respect human rights, the right to life, the prohibition of torture, the prohibition of slavery and forced labor, the right to freedom and personal inviolability, the right to a fair trial, the right to respect for private and family life, freedom of thought, conscience and religion, etc. - as the Council of Europe understands them ${ }^{18}$.

The European Social Charter ${ }^{19}$ articulates not less important values and principles by complementing the Convention and creating a holistic range of internationally recognized human rights standards with it.

More local and substantive human rights activities carried out by the UNESCO international organization. It develops and advocates cultural rights: to education, the use of scientific achievements, unimpeded participation in cultural life, and so on. In this case, the organization develops recommendations establishing and guaranteeing human cultural rights and freedoms.

\footnotetext{
18 Європейська конвенція 3 прав людини. URL: https://www.echr.coe.int/Documents/ Convention_UKR.pdf.

19 Європейська соціальна хартія (переглянута). від 14.09.2006 р. № 137-V. Дата оновлення: 07.09.2016 p. URL: https://zakon.rada.gov.ua/laws/show/994_062.
} 
On November 25, 2015, an international conference "Moldova, Georgia, Ukraine: the Issue of Occupied Territories and Frozen Conflicts" was held in Kyiv. The event was about the emergence of a new reality, triggered by terrorist acts in Europe, the war in the Middle East, and most of all - the annexation of the Crimea and military aggression of Russia in Donbas.

In this context, the so-called "frozen conflicts" require rethinking. The event participants came to the conclusion that the situation requires coordination of actions of Ukraine, Georgia and Moldova, which are experiencing the same problems and have a common source of these problems, namely, aggression of the Russian Federation. Practice shows that each of these three countries is not able to stand alone against Russia, which deliberately transforms all occupied territories into "gray zones". To that end, the efforts should be united at the level of governments, human rights activists, and people of Ukraine, Moldova and Georgia. Moreover, the initiative should come from public circles. Under current political conditions, Ukraine, Moldova and Georgia should, by cooperating, create an evidence base for Russian engagement in exasperating of conflicts and deliberately blocking the resolution of these conflicts.

Delaying the resolution of socio-economic, political-legal, and military-political conflicts in the temporarily occupied territories of Ukraine is disastrous for both the state and citizens.

This is also confirmed by international judicial practice, in particular, the practice of the European Court of Human Rights, for example, the Resolutions of June 16, 2015 of the ECHR in the case of "Chiragov and others v. Armenia", «Ilascu and others v. Moldova and Russia."

In the case of "Chiragov and others v. Armenia" the issue which of the states - Armenia or Azerbaijan - is responsible for observance of human rights at the territory of so-called "Nagorno-Karabakh Republic" ("NKR") was being resolved. Considering this case, the representatives of Armenia adhered to the principle of "we are not there". In this regard, the ECHR had to admit: “... It is strange to perceive the statements of representatives of the Republic of Armenia, which, apparently, contradict to the official position that the Armenian Armed Forces are not located in "NKR" or at the adjacent territories." The court indicated that, it establishes based on numerous reports and statements, that the Republic of Armenia, as a result of its military presence and provision of military equipment and specialist knowledge, has been significantly involved in 
the Nagorno-Karabakh conflict from the beginning. Thus, as a result of consideration of this case, the ECHR has in fact recognized the occupation of part of the Azerbaijan territory ("NKR") by Armenia, hence, the responsibility of Armenia for the observance of human rights at this territory. In the ECHR Decision it was about: "Article 42 of The Convention respecting the laws and customs of war on land (Hague Convention of 1907) determines military occupation as follows: Territory is considered occupied when it is actually placed under the authority of the hostile army... The requirement of actual authority is widely recognized as a synonym of effective control" 20 .

Relevant legal positions were also found in the ECHR decision in the case of "Ilascu and others v. Moldova and Russia", dealing with violations of human rights in Transnistria and actions of a "hybrid occupier". The ECHR emphasized: although the international legal understanding of the term "within the jurisdiction" is associated with a territory of the state, jurisdiction may also be exercised outside the territory of the state. There can be exceptions when the state does not fully exercise power over a part of its territory, in particular as a result of armed occupation by another state that controls that territory (clause 312 ). State responsibility can take place in the course of military actions (lawful and unlawful), if in practice the state exercises effective control outside the national territory. The obligation to ensure the human rights and freedoms at this territory follows from the fact of such control through the presence of armed forces or management bodies at this territory. When a state exercises control outside its national territory, its liability is not limited to the actions of soldiers and officers, and is related to the actions of local administration. The state can be liable, even if its agents act contrary to its instructions (clauses 316, 319). The Moldavian government (under international law, the only legitimate government of the Republic of Moldova) did not exercise power over a part of its territory that was under the control of the Republic of Transnistria (clause 330). From the point of view of the ECHR, Moldova had too little chance to establish control over Transnistria, taking into account that the regime was supported by the Russian Federation by political, economic and military means (clause 341 of the Decision). Liability of the RF arises in connection with illegal

\footnotetext{
${ }^{20}$ Чирагов и другие против Армении: Постановление ЕСПЧ от 16.06.2015 г. (жалоба № 13216/05). URL: http://zakoniros.ru/?p=22677.
} 
actions of the Transnistrian separatists, in view of the support of these actions by the RF (clause 382$)^{21}$.

It appears from the European Court of Human Rights practice: occupation regimes, having various names ("effective control", temporarily occupation etc.), are almost the same in fact. And liability concerning seized territories in accordance with international legal standards, national legislation, is born by an occupier-state.

Therefore, the institution of liability must be, firstly, thoroughly regulated, and secondly, a functional tool suitable for overcoming the consequences of the hybrid war and occupation, compensation of damage by an occupier-state, and thirdly, a highly effective factor of influence in order to prevent similar acts in the future.

Thus, the concepts of "annexation" and "occupation" are not absolutely the same.

A state establishes a specific legal regime both on occupied and annexed territories. At the same time, an aggrieved state, protecting its territory and people, has the right to use all available international legal means.

Today, a legal regime of occupied territories is enshrined in national legislation in Ukraine. However, there are complex problems: determination of legal regime of annexed territories, legal regulation of issue on legal status of territories in the area of anti-terrorist operations.

\section{CONCLUSIONS}

Legal policy of the state at temporarily occupied territories under the conditions of a hybrid war is a type of legal policy, and the latter is an independent type of the state policy.

Legal policy at temporarily occupied territories under the conditions of a hybrid war, has its own types: 1) by different fields of right exercise: legal, punitive-corrective, executive, judicial, notarial, prosecutorial etc.; 2) by law branch: constitutional-legal; criminal-legal; civil-legal; administrative-legal etc.; 3 ) by law structure in the field: private; public; material; procedural; regulatory; protective; 4) by fields of society: economics; politics; culture: 5) by territorial feature: nation-wide; local; 6) by elements of legal system: law-making; law-exercising; laweducating; 7) depending on the aim of exercise: current and prospective.

21 Илашку и другие против Молдовы и России: Решение ЕСПЧ от 08.07.2004 г. (жалоба № 48787/99. URL: http://sutyajnik.ru/rus/echr/judgments/ilascu_rus.htm. 
The principles of the state legal policy at the temporarily occupied territories under the conditions of a hybrid war include the following: the priority of human rights; legality; social conditionality; scientific justification; firmness and predictability; legitimacy; morality; justice; publicity; unification of interests of a person and the state; compliance with international standards; objectivity; adequacy; optimality; reasonability; systematic nature; purposefulness; sequence; resource provision; humanistic orientation and democratic character of the toolkit.

The state legal policy at the temporarily occupied territories in a hybrid war is a part of the state policy that is justified and consistent activity of state authorities and local self-government bodies in order to provide an effective mechanism for the legal regulation of public relations at temporarily occupied territories under the conditions of a hybrid war and it is expressed in a set of ideas, activities, tasks, programs, guidelines implemented in the field of law and through the law and based on the fundamental legal principles.

The components of the state legal policy at temporarily occupied territories under the conditions of a hybrid war are not stable. The structure is not clear, and the list can not be considered as complete. After all, public relations are changing all the time, and therefore the structure of legal policy itself can change, adapting to the requirements of civil society. During the hybrid war, the state further strengthens the law order, using, as a rule, coercion. Therefore, the priority of law order and national safety can be a sign of legal policy. The subjects of the state legal policy regarding temporarily occupied territories during a hybrid war can be considered: 1) the state, carrying out its functions in exercise of legal policy through certain bodies and institutions directly; 2) political parties; 3) citizens (civil society). Sometimes foreign states and states-participants in the hybrid war can also be the subjects.

Despite the different names (temporary occupation, "effective control", etc.), the ECHR practice proves that such regimes are actually the same, but the liability for acts committed against these territories is borne by a state-occupier in accordance with existing international legal standards, legitimate national legislation.

It is the institution of liability that should be not only properly regulated but also a truly functioning, effective tool for overcoming the negative consequences arising from the completion of a hybrid war and hybrid occupation, reimbursement of damage by guilty parties, and in order to prevent similar actions in the future. 
The concepts of "annexation" and "occupation" are not identical. Both during occupation and annexation, a special legal regime of occupied or annexed territories is introduced in the state. During occupation or annexation the aggrieved state has the right to use all legal international means to protect its territory and citizens.

\section{REFERENCES:}

1. Про Рекомендації парламентських слухань на тему: «Стан дотримання прав внутрішньо переміщених осіб та громадян України, які проживають на тимчасово окупованій території України та на тимчасово неконтрольованій території в зоні проведення антитерористичної операції»: Постанова Верховної Ради України від 31.03 .2016 p. № 1074-VIII. URL: http://zakon0.rada.gov.ua/ laws/show/1074-19.

2. Конституція України: Закон України від 28.06.1996 р. № 254к/96-BP. Дата оновлення: 21.02.2019 p. URL: http://zakon2.rada.gov.ua/laws/show/254к/96-вр.

3. Попова Т. До питання відновлення суверенітету України над тимчасово окупованими територіями. URL: https://www.google.com.ua/url?sa=t\&rct=j\&q=\&esrc=s\&source=web\&cd $=33 \&$ cad $=$ rja\&uact $=8 \& v e d=0$ ahUKEwj_tO6gi_XXAhWsZpoKHbW4Cx w4HhAWCDYwAg\&url=https\%3A\%2F\%2Fwww.radiosvoboda.org\%2F a\%2F28842999.html\&usg=AOvVaw0TAk1KLnYOb3JSfhpSpwwW.

4. Задорожній О. В. Анексія Криму - міжнародний злочин: монографія. Київ: К.І.С., 2015. 576 с.

5. Тлумачення та застосування Конвенції про захист прав людини й основоположних свобод Європейським судом 3 прав людини та судами України : навч. посіб. / [М. В. Мазур, С. Р. Тагієв, А. С. Беніцький та ін.]; за ред. В. М. Карпунова. - Луганськ: РВВ ЛДУВС, 2006. 600 с.

6. Свропейська конвенція 3 прав людини. URL: https://www.echr.coe.int/Documents/Convention_UKR.pdf.

7. Короткий термінологічний словник. URL: https://pidruchniki.com/11800408/istoriya/politichna_istoriya_ukrayini_sl ovnik

8. Словник української мови. Академічний тлумачний словник (1970-1980). URL: http://sum.in.ua/s/okupacija.

9. Словник іншомовних слів. URL: http://slovopedia.org.ua/ 36/53406/244881.html. 
10. Полтавець С. Окупація земель суверенної держави: уроки політичної iсторії. URL: http://nbuviap.gov.ua/index.php?option= com_content\&view=article\&id=972:okupatsiya-zemel-suverennojiderzhavi\&catid $=8 \&$ Itemid $=350$.

11. Курбан О.В.Теорія інформаційної війни: базові основи, методологія та понятійний апарат. Scientific Journal «ScienceRise». 2015. № 11/1 (16). С. 95-100.

12. Окупація та ефективний контроль: національне сприйняття та міжнародно-правові реалії. URL: https:/mtot.gov.ua/okupatsiyata-efektyvnyj-kontrol-natsionalne-spryjnyattya-ta-mizhnarodno-pravovirealiyi.

13. Горбулін В. Гібридна війна: все тільки починається ... Дзеркало тижня. 25.03.2016 p. № 11. URL: http://gazeta.dt.ua/internal/ gibridna-viyna-vse-tilki- pochinayetsya-html.

14. Правовий режим окупованої території. URL: http://www.ilaw.kiev.ua/правовий-режим-окупованої-територіï/

15. Paraskeva Costas. Protecting internally displaced persons under the European convention on human rights and other Council of Europe standards: a handb. Харків: Pravo, 2017. 130 p.

16. Європейська соціальна хартія (переглянута). від 14.09.2006 p. № 137-V. Дата оновлення: 07.09.2016 p. URL: https://zakon.rada.gov.ua/laws/show/994_062.

17. Чирагов и другие против Армении: Постановление ЕСПЧ от 16.06.2015 г. (жалоба № 13216/05). URL: http://zakoniros.ru/?p=22677.

18. Илашку и другие против Молдовы и России: Решение ЕСПЧ от 08.07.2004 г. (жалоба № 48787/99. URL: http://sutyajnik.ru/rus/ echr/judgments/ilascu_rus.htm.

\section{Information about the author:} Iliashko O. O.

Candidate of Juridical Sciences, Assistant Professor at the Department of Constitutional and International Law of the Educational-Scientific Humanitarian Institute of the V. I. Vernadsky Taurida National University

33, Ivana Kudri str., Kyiv, Ukraine 